\title{
The Barriers to High-Growth Enterprises: What Do Businesses in Africa Experience?
}

\author{
Chinyere Augusta Nwajiuba ${ }^{1}$, Paul Agu Igwe ${ }^{2 *}$, Micheal Olayinka Binuomote ${ }^{3}$, \\ Anulika O. Nwajiuba ${ }^{4}$, Kenneth Chukwuma Nwekpa ${ }^{5}$
}

\begin{abstract}
This study examines the challenges that micro, small and medium enterprises (MSMEs) face and provide insights on African business environment and entrepreneurial ecosystem. In the context of growth-oriented entrepreneurship, good policies and favourable institutional environments support firms' growth, productivity and development, while adverse formal and informal institutions constrain business development. Secondary data from World Bank Enterprise Survey (WBES) was used to capture barriers to entrepreneurship and high-growth opportunities which include - lack of finance, lack of innovation and technology, low skilled workforce, poor infrastructure, unfavorable regulations and more pervasively corruption. These barriers are evident in the micro, meso and macro environments. These have implications on the unemployment rate, poverty rates and economic growth of the African region.
\end{abstract}

Keywords: Micro, Small and Medium Enterprises; Entrepreneurial Ecosystem; African Entrepreneurship; African Business Environments.

\section{Introduction}

Research into the contribution of micro, small and medium enterprises (MSMEs) to the growth of developed and developing economies have taken centre stage (Santos, Roomi \& Liñán, 2016; Sheriff and Muffatto, 2015; Nsengimana, Tengeh \& Iwu, 2017). While evidence from empirical research acknowledged MSMEs importance, it also raises alarm on its high rate of failure and underperformance (Kellermanns et al., 2016). Therefore, this article examines the barriers that African entrepreneurs face starting up MSMEs and the difficulty that confronts those who are already engaged in MSMEs and want to grow their businesses. African entrepreneurship is gradually evolving in the face of global economic, political, technological and social changes (Jones et al., 2018). Also, social entrepreneurship is emerging (Igwe, Icha-Ituma \& Madichie, 2018; Jaki \& SiutaTokarska, 2019) where entrepreneurs embark on corporate social, ethical and environmental responsibilities.

\footnotetext{
${ }^{1}$ Ag. Director, Centre for Enhancement of Teaching and Learning, Alex Ekwueme Federal University, Ndufu-Alike (AE-FUNAI) PMB 1010 Abakaliki, Ebonyi State, Nigeria

2* - Corresponding Author, Senior Lecturer \& Programme Leader, Lincoln International Business School University of Lincoln, United Kingdom, Brayford Wharf East, Lincoln, LN5 7AT

${ }^{3}$ Head of Department, Department of Vocational \& Technical Education(Business Education), Alex Ekwueme Federal University Ndufu Alike, Ikwo (FUNAI), P.M.B. 1010, Abakaliki, Ebonyi State, Nigeria ${ }^{4}$ Lecturer, Department of Account/Business Management, Alex Ekwueme Federal University Ndufu Alike, Ikwo, P.M.B. 1010, Abakaliki, Ebonyi State, Nigeria

${ }^{5}$ Senior Lecturer, Faculty of Management Sciences, Ebony State University, Abakaliki, Nigeria.
} 
The context being examined is a typical African business environment. Research has shown that the number of micro-businesses with fewer than 10 workers in the developing countries context is disproportionately more than what is observed in the developed world contexts (McKenzie, 2015). Furthermore, most of these businesses are generally informal and/ or family-run ventures (López-Fernández et al., 2016). Features of informality include having fewer than five employees, being unregistered and typically do not pay taxes (Khavul et al., 2009). More so, MSMEs are disadvantaged in markets for entrepreneurial resources when compared to large firms. If this is indeed the case, there is a "business case" for more research on discourses of African business environment and the entrepreneurship ecosystem.

The Global Entrepreneurship Monitor (GEM, 2015) data reveals that on the surface, entrepreneurship looks healthier in Africa compared to other regions. However, there are two important caveats to this. First, it is suggestive of the 'necessity versus opportunity' argument where the quality of the opportunity and corresponding value that can be extracted may be lower in the African context (African Development Bank, ADB, 2012 \& 2019). Second, the majority of the activities are 'necessity-driven' (Igwe, Madichie \& Newbery, 2019). Consequently, African economic outlook shows that the continent is experiencing youth's jobless growth with around 60 per cent of unemployed youths (ADB, 2012). To overcome the unemployment challenge, International Fund for Agricultural Development (IFAD, 2012, p. 7) posits that many governments in Africa, development organisations and aid donors have made the promotion of small-scale enterprises a major policy concern.

However, there is evidence from past studies that barriers to MSMEs growth exist. Therefore, Isenberg (2010 \& 2011) model of the entrepreneurial ecosystem is used to examine the barriers to MSMEs based on a cross-regional and countries analysis. The African regions and countries examined include Mozambique (South), Egypt (North), Chad (Central), Kenya (East) and Gambia (West). The main questions explored in this study include: What is the entrepreneurial ecosystem in which MSMEs operate? What kind of policies and institutional environments hinder entrepreneurship? How does the entrepreneurial ecosystem in African vary across the regions and countries? By examining these questions, we hope to contribute to knowledge about African entrepreneurship research. First, it explores the entrepreneurial ecosystem model, followed by an exploration of African entrepreneurship and business environment. Next, we describe the research method and data source, followed by the analysis and discussion. Finally, we conclude with some recommendations.

\section{Literature Review}

\subsection{Entrepreneurial Ecosystem}

Institutions affect a firm's performance (Zoogah, 2018). Institutions (formal and informal rules) govern individual behaviour (North, 1990; Anggadwita, Ramadani \& Ratten, 2017; Igwe et al., 2018). Isenberg (2010 \& 2011) presented a model of entrepreneurial ecosystems (EE) to analyse the factors that support or hinder entrepreneurial growth (Sheriff \& Muffatto, 2015) in many regions. The EE model consists of six main elements which are: Policy, Finance, Culture, Support, Human Capital and Markets (Isenberg, 2011). This model of EE has been adopted in many 
studies (Mack \& Mayer, 2015; Maroufkhani et al., 2018; Nsengimana, Tengeh \& Iwu 2017). More than 95 per cent of businesses in the world fall into MSMEs category (Meghana, Demirguc-Kunt \& Maksimovic, 2011) and the majority are low-growth firms. Previous entrepreneurship researchers have explored in-depth the determinants of entrepreneurial venture performance (Kellermanns et al., 2016). Some studies attribute lower levels of MSMEs and growth-oriented entrepreneurship to differences in access to key resources (Menzies et al., 2004; Terjesen, 2016; World Bank, 2008). In the context of growth-oriented entrepreneurship (Aikaeli, 2010), there is a consensus that good policies (regulations, taxation, exporting and importing conditions) increase entrepreneurship, while harsh environment and policies constrain business development and growth (Herrera \& Kouamé, 2017). Access to finance has been cited as the most crucial factor and an impediment to the growth of MSMEs (Robb, Coleman \& Stangler, 2014).

Another major challenge that has impeded entrepreneurship is culture. Culture is directly associated with institutions in the sense that culture, as an informal institution as defined by North (1990), govern individual behaviour (Boettke \& Coyne 2009; Ajekwe 2017; Anggadwita, Ramadani \& Ratten, 2017). The problem of corruption appears embedded in African cultural and traditional practices (Hechavarría et al., 2017; Williams \& Kedir, 2016). Among these economic development constraints is human capital related to the lack of skilled labour and low levels of education (World Bank, 2008). This is because many African countries are still at an early stage of economic development (GEM, 2014; Santos et al., 2016). Also, gender discrimination regarding employment and women entrepreneurship (McGowan et al., 2015). The World Bank (2013) maintains that about 90 per cent of countries continue to have laws or regulations that prevent women from productive entrepreneurship.

\subsection{African Entrepreneurship and Business Environment}

There is a paucity of research about entrepreneurship in Africa (George et al., 2016). However, there an increasing interest in African entrepreneurship in academic and policy domain aimed at closing the knowledge gaps (Jones et al., 2018), however, challenges remain. Some of the challenges include limited evidence-based policy, weak entrepreneurial ecosystem, lack of innovation, research and development (World Bank, 2015). Besides, there is a lack of institutional supports for entrepreneurship (Igwe et al., 2018). Indeed, the entrepreneurial ecosystem in many African countries produces micro, small and informal enterprises. Arguably, the majority of these enterprises are necessity entrepreneurship (GEM, 2014 \& 2015; Igwe, Madichie \& Newbery, 2019) as a result of the high rate of unemployment and poverty in the region. Above all, the adverse entrepreneurial ecosystem, culture and regulations prevent those who want to become entrepreneurs and entrepreneurs who want to grow their businesses.

\section{Research Method}

This paper adopts the secondary data and desk research approach (Cheng \& Phillips, 2014). This approach involves using information gathered through other sources. One of the advantages is that the information already exists and is readily available (that is quick to use $\&$ low cost). Another advantage is that it can provide the 
foundation for future primary research (Cheng \& Phillips, 2014). The limitation of this method comes with lacks specificity of the information and some secondary data may be of suspect quality or outdated, etc. Mostly, the data used for this study comes from the World Bank Enterprise Survey (WBES) that measures business environment based on 135,000 firms in 139 countries. We have employed data from the WBES to provide a cross-regional and countries analysis based on Southern region (Mozambique), North (Egypt), Central (Chad), East (Kenya) and West (Gambia).

\section{African Economic Outlook and Challenges}

The five countries captured in this study are mainly lower middle income and low-income countries. As revealed in Table 1, these countries include Egypt, Mozambique, Chad, Kenya and Gambia located within North and Sub-Saharan Africa. The challenges of doing business in Africa are widely known such as weak infrastructure; immature capital markets; poor quality of education; low gross domestic product (GDP) per capita, which leads to low demand (World Economic Forum, 2019). As such Africa's sustainable economic and social transformation is a global priority (Organization for Economic Co-operation and Development, OECD, 2019). Africa's economic performance continues to improve, with GDP growth reaching about 3.5 per cent in 2018 (African Development Bank, 2019). In the context of entrepreneurship, about 22 per cent of Africa's working-age population are starting new businesses; the highest entrepreneurship rate in the world (African Development Bank, 2013). Ekekwe (2016) provides some reasons why African entrepreneurship is booming. Entrepreneurs are using materials sourced locally. Mobile technology, open-source software and ideas from local technology hubs are supporting entrepreneurs and companies create their innovations (Ekekwe, 2016). Leveraging the power of digital technologies, African entrepreneurs now have the capacity of technology to solve problems and match the scale of market challenges (World Economic Forum, 2019).

Table 1. Overview of the Study Regions/Countries

\begin{tabular}{|c|c|c|c|c|c|c|}
\hline Countries & Region & $\begin{array}{l}\text { Income } \\
\text { Category }\end{array}$ & Population & $\begin{array}{l}\text { GNI PER } \\
\text { CAPITA } \\
\text { (US\$) }\end{array}$ & $\begin{array}{l}\text { Number } \\
\text { of Firms } \\
\text { Surveyed }\end{array}$ & Year \\
\hline Egypt & $\begin{array}{l}\text { The Middle East } \\
\text { \& North Africa }\end{array}$ & $\begin{array}{l}\text { Lower- } \\
\text { middle } \\
\text { income }\end{array}$ & $97,553,151$ & 3,010 & 1,814 & 2016 \\
\hline Mozambique & $\begin{array}{l}\text { Southern } \\
\text { Africa/Sub- } \\
\text { Saharan }\end{array}$ & Low-income & $29,668,834$ & 420 & 601 & 2018 \\
\hline Chad & $\begin{array}{l}\text { Central } \\
\text { Africa/Sub- } \\
\text { Saharan }\end{array}$ & Low-income & $14,899,994$ & 630 & 153 & 2018 \\
\hline Kenya & $\begin{array}{l}\text { East African/Sub- } \\
\text { Saharan }\end{array}$ & $\begin{array}{l}\text { Lower- } \\
\text { middle } \\
\text { income }\end{array}$ & $49,699,862$ & 1440 & 1001 & 2018 \\
\hline The Gambia & $\begin{array}{l}\text { West Africa/Sub- } \\
\text { Saharan }\end{array}$ & Low-income & $2,100,568$ & 450 & 151 & 2018 \\
\hline
\end{tabular}


Another feature is that most African countries fall into factor-driven economies. According to GEM (2018) classification, the factor-driven economies are dominated by subsistence agriculture and extraction businesses, with a heavy reliance on (unskilled) labour and natural resources. As development advances into the innovation-driven phase, businesses are more knowledge-intensive and expands into the service sector (GEM, 2018). As revealed in Figure 1, Egypt has the lowest ranking related to per cent of firms using technology licensed from foreign companies (5.1\%), per cent of firms that introduced a new product/service $(5.7 \%)$ of firms that introduced a process innovation $(4.0 \%)$ and per cent of firms that spend on research and development (R\&D) $(3.2 \%)$.

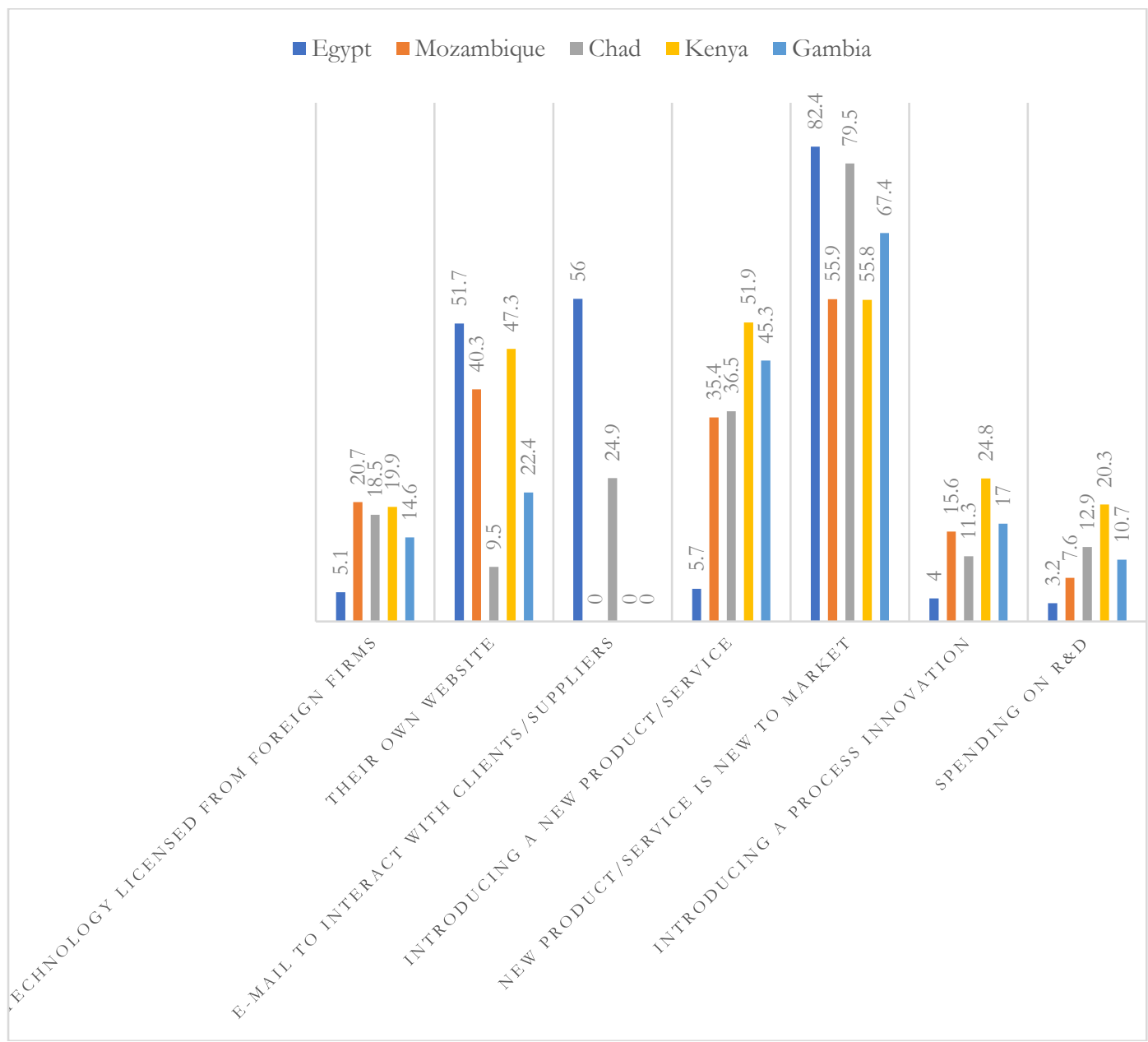

Figure 1. Application of Innovation and Technology (per cent of firms using or introducing)

Data from GEM (2018) reveal that the entrepreneurship ecosystem is strongest overall in the innovation-driven economies than in factor-driven economies such as Africa. However, African context provides the most fertile environment in which to innovate, because it is where these problems are most deeply felt and are big enough both to 
motivate investment and recover the cost of that investment (World Economic Forum, 2019). Obstacles to business environment vary from one country to another as reveal in Figure 2. However, in general, most individuals in Africa have a high perception for starting a business, the continent has most women in business, however, many are necessity-driven entrepreneurship (GEM, 2012).

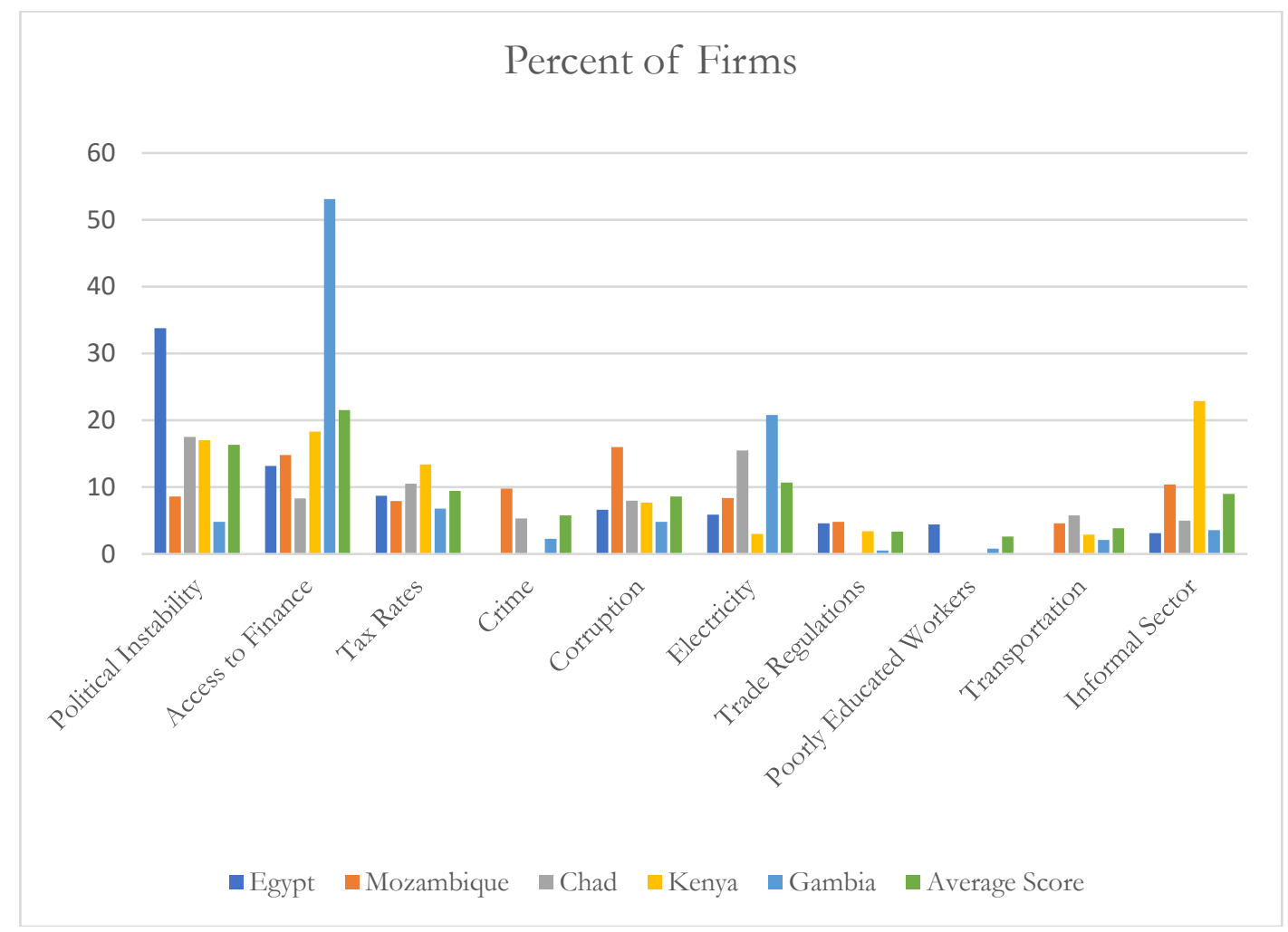

Figure 2. Top Business Environment Obstacle for Firms (\% of firms choosing the obstacle)

Socioeconomic conditions constrain business performance and growth (Zoogah, 2018). Poverty, corruption and social dissatisfaction of government actions represent other forms of challenges that hinder entrepreneurship and enterprise growth in many African countries (Aidt 2009; Méon \& Sekkat 2005). As shown in Table 2, bribery incidence is highest in Kenya (23.2), followed by Chad (27.4), Mozambique (21.1), Egypt (15.2) and Gambia (9.2). Aidis, Estrin and Mickiewicz (2012) argue that corruption constrains entrepreneurship by deterring entrepreneurs unwilling to engage in corrupt practices and encouraging unproductive forms of entrepreneurship. 
Table 2. Corruption (Percentage of firms)

\begin{tabular}{|c|c|c|c|c|c|}
\hline & Egypt & Mozambique & Chad & Kenya & $\begin{array}{l}\text { The } \\
\text { Gambia }\end{array}$ \\
\hline Bribery incidence & 15.2 & 21.1 & 27.4 & 23.2 & 9.2 \\
\hline Bribery depth & 13.6 & 14.9 & 22.5 & 17.6 & 6.7 \\
\hline Give gifts in meetings & 13.2 & 13.5 & 21.0 & 20.9 & 5.6 \\
\hline Tips to secure a contract & 14.2 & 25.9 & 33.0 & 34.0 & 12.8 \\
\hline Give gifts to get operating License & 20.7 & 12.4 & 20.1 & 10.1 & 7.4 \\
\hline $\begin{array}{l}\text { Give gifts to get a construction } \\
\text { permit }\end{array}$ & 27.9 & 34.8 & 69.4 & 30.0 & 20.9 \\
\hline $\begin{array}{l}\text { Give gifts to get an electrical } \\
\text { connection }\end{array}$ & 2.0 & 30.2 & 35.8 & 33.7 & 0 \\
\hline $\begin{array}{l}\text { Give gifts to get a water } \\
\text { connection }\end{array}$ & 25.6 & 21.1 & 23.2 & 21.9 & NA \\
\hline $\begin{array}{l}\text { Give gifts to public officials "to get } \\
\text { things done" }\end{array}$ & 19.0 & 14.1 & 38.0 & 26.3 & 12.8 \\
\hline Corruption as a major constraint & 68.2 & 32.4 & 39.6 & 41.6 & 15.8 \\
\hline Ineffective Legal system & 24.0 & 8.0 & 25.4 & 9.4 & 7.4 \\
\hline
\end{tabular}

Other socio-economic elements such as crime, state of infrastructure, taxes and trade regulations also impact on firm performances. WBES data reveal that the percentage of firms identifying crime, theft and disorder as a major constraint as follows: 27.8 (Chad), 25.2 (Mozambique), 10.3 (Egypt), 8.2 (Gambia) and 7.9 (Kenya). Per cent of firms experiencing electrical outages from WBES showed 93.2 (Gambia), 82.8 (Kenya), 70.2 (Chad), 52.8 (Mozambique) and 38.0 (Egypt). From the WBES data, the percentage of firms identifying business licensing and permits as a major constraint varies from 34.1 (Egypt), 15.4 (Kenya), 14.0 (Chad), 11.2 (Mozambique) and 10.1 (Gambia). While the percentage of firms identifying tax rates as a major constraint 47.8 (Egypt), 45.6 (Chad), 43.3 (Gambia), 36.1 (Kenya) and 17.9 (Mozambique). Finally, the percentage of firms identifying customs and trade regulations as a major constraint 27.4 (Chad), 20.1 (Egypt), 19.4 (Gambia), 17.4 (Kenya) and 10.2 (Mozambique). The factors have resulted in low real annual sales growth (\%) 6.9 (Gambia), 5.7 (Egypt), 1.6, (Mozambique), 1.5 (Kenya) and -3.2 (Chad), and negative annual labour productivity growth.

\section{Conclusion and Recommendations}

Entrepreneurship is regarded as an important mechanism across regions for economic development and as a means for generating employment and poverty reduction. This article contributes to understanding the barriers that MSMEs face and the nature of the entrepreneurial ecosystem and the business environment in Africa. The economy of majority African countries has been improving in the last decade, however, African countries fall into lower-income and lower-middle-income when compared to the rest of the world according to the World Bank Enterprise Survey. More so, the majority of African countries fall into factor-driven economies, hence advances in innovation and technology is low (GEM, 2014 \& 2015). This has an impact on businesses given the globalization and internationalization of firms. 
Although, entrepreneurship and business activities are high in African region (Goedhuys \& Sleuwaegen, 2010), these activities reflect informal activities (Igwe, Newbery \& IchaItuma, 2018) and necessity entrepreneurship (see, Igwe, Madichie \& Newbery, 2019) due partly to the high unemployment rate, high poverty rates, low education, lack of adequate business support such as finance, infrastructure, unfavourable regulations, etc. Also, this article illustrates the impact of institutional arrangements, as well as the entrepreneurial ecosystem and their impact on entrepreneurship, business performance and growth. Among the top barriers to entrepreneurship and MSMEs growth include finance, corruption, political instability, unskilled workforce, crime, taxation, customs and trade regulations.

Access to finance is a major barrier reflected in the lack of access to credit to many MSMEs by financial institutions and lending banks (Khuvul, 2010). Typically, owners of micro and small enterprises lack information, credit history and collateral required by the traditional lending institutions (see, e.g. Khavul, 2010, Mishra et al., 2015). As a result, many low income and poor are excluded from formal financial arrangements services and rely on informal lenders (Mishra et al., 2015). Another barrier is the knowledge, skills and competence of the workforce. In many African countries, lack of entrepreneurship/vocational education is still a major constraint. These lead to high graduate unemployment (Okunuga \& Ajeyalemi, 2018; Pitan, 2016 \& 2017).

Culture is part of an informal institution that determine individual behaviour and affect entrepreneurship. Corruption is a major factor in this regard (Faleye 2013; Keeper 2012; Hechavarría et al. 2017). Although there are two contrasting views regarding the effect of corruption on firms performance (Méndez \& Sepúlveda 2006; Méon \& Weill 2010; Williams \& Kedir, 2016; Zoogah, 2018), the consensus is that corruption increases business transaction costs and deter some people who do not want to engage in corruption from doing business (Igwe, Madichie \& Newbery, 2019; Igwe, Onjewu \& Nwibo, 2018; Igwe et al., 2018). Other business obstacles and barriers include crime rates, access to infrastructure, high tax rates and trade regulations.

This study proposes that new policies are required to provide enabling entrepreneurial ecosystem, increase entrepreneurship and improve the growth of micro and small enterprises. This will act as an engine for (1) innovation and growth (given that most economies in the region fall into factor-driven) and (2) help reduce unemployment and poverty rates. Across African countries, studies, show that these are the two most curial elements to African socio-economic development. Hence, we recommend that the government take the necessary steps to address many of the barrier affecting entrepreneurship and business growth (Naudè \& Havenga, 2005). First, access to finance will require reducing some barriers that traditional banks have as conditions for lending to borrowers (especially low-income people). Also, more microfinance banks and traditional banks should be encouraged to open rural branches. Secondly, we suggest reforms in taxation, imports and export regulations in the context of globalization to enable African entrepreneurs to compete favourably globally. Third, the government and private sector should focus on improving infrastructures such as road, rail, electricity and internet services. These will reduce the cost of doing business and encourage new startups. Fourth, entrepreneurship and vocational education are required at all levels of 
education, primary, secondary and tertiary to develop knowledge, skills and competencies necessary for management and business operations.

Finally, the majority of previous entrepreneurship research has traditionally focused on developed economies, partly driven by the availability of firm-level panel datasets, both on the national and regional levels. This is not the case in African entrepreneurship research due to lack of available database and the difficulty in collecting data. Hence, this study contributes to the knowledge of African entrepreneurship and barriers to business growth. However, one of the major limitations is the reliance on secondary data. However, the data from WBES and GEM which we have used for the analysis are robust and credible data sources. Therefore, this study provides a foundation for future qualitative and quantitative studies.

\section{References}

African Development Bank (ADB 2012). Africa's demographic trends; a briefing note for AfDB's long-term strategy. In the European Centre for Development Policy Management (2014), Africa's Youth Goldmine: AfDB's response to youth employment crisis in Africa, accessed 10 April 2016 at http://ecdpm.org/great-insights/fostering-more-and-better-jobs/response-youth-employmentcrisis-africa/

African Development Bank (ADB, 2013). Recognizing Africa's informal sector, 27, March 2013. Accessed 02/11/2018, $\quad \underline{\text { https://www.afdb.org/en/blogs/afdb-championing-inclusive-growth-across- }}$ africa/post/recognizing-africas-informal-sector-11645/

African Development Bank (ADB, 2019). African Economic Outlook 2019. https://www.afdb.org/en/knowledge/publications/african-economic-outlook

Aidis, R., Estrin, S., \& Mickiewicz, T. (2012). Size matters: Entrepreneurial Entry and Government. Small Business Economics, 39, 119-139.

Aidt, T. S. (2009). Corruption, Institutions, and Economic Development. Oxford Review of Economic Policy, 25 (2): 271-91. doi:10.1093/oxrep/grp012

Aikaeli, J. (2010). Determinants of Rural Income in Tanzania. “An Empirical Approach” Research on Poverty Alleviation REPOA, $10 / 4$.

Ajekwe, C. C. (2017). Effect of Culture on Entrepreneurship in Nigeria. International Journal of Business and Management Invention, 6(2), 1-6.

Anggadwita, G., V. Ramadani and Ratten, V. (2017). Sociocultural environments and emerging economy entrepreneurship Women entrepreneurs in Indonesia. Journal of Entrepreneurship in Emerging Economies, 9(1), 85 - 96. http://dx.doi.org/10.1108/JEEE-03-2016-0011

Boettke, P. J. and Coyne, C. J. (2009). Context matters: Institutions and Entrepreneurship. Foundations and Trends in Entrepreneurship, 5(3), 135-209.

Cheng, H. G. and Phillips, M. R. (2014). Secondary analysis of existing data: opportunities and implementation. Shanghai archives of psychiatry, 26(6), 371-375. doi:10.11919/j.issn.1002-0829.214171

Ekekwe, N. (2016). Why African Entrepreneurship Is Booming? Harvard Business Review. July 11, 2016. https://hbr.org/2016/07/why-african-entrepreneurship-is-booming

Faleye, O. A. (2013). Religious Corruption: A Dilemma of the Nigerian State. Journal of Sustainable Development in Africa, 15(1), 1520-5509.

GEM (2012) African Entrepreneurship. https://www.babson.edu/media/babson/site-assets/contentassets/about/academics/centres-and-institutes/blank-institute/global-research/globalentrepreneurship-monitor/reports/GEM-2012-Africa-Report.pdf

GEM (2014). Africa's Young Entrepreneurs: Unlocking the Potential for a better future'. Global Entrepreneurship Monitor UK. United Kingdom Monitoring Report. file:///H:/Downloads/1425737316GEM UK 2014 final.pdf Accessed Nov. 25, 2017 
GEM (2015). Africa's Young Entrepreneurs: Unlocking the Potential for a better future. Accessed: 05/06/2018 https://www.idrc.ca/sites/default/files/sp/Documents\%20EN/Africas-YoungEntrepreneurs-Unlocking-the-Potential-for-a-Brighter-Future.pdf

GEM (2018). Global Report. file:///C:/Users/SurfBook/Downloads/rev-gem-2017-2018-global-reportrevised-1527266790-1548584425-1549359513.pdf

George, G., Corbishley, C., Khayesi, J., Haas, M. and Tihanyi, L. (2016), 'Bringing Africa in promising directors for management research', Academy of Management Journal, 59 (2), 377-393.

Goedhuys, M. and Sleuwaegen, L. (2010). High-growth Entrepreneurial Firms in Africa: A Quantile Regression Approach. Small Business Economics, 34(1), 31-51.

Hechavarría, D. M., S. A. Terjesen, A. E. Ingram, M. Renko, R. Justo and Elam, A. (2017). Taking Care of Business: The Impact of Culture and Gender on Entrepreneurs' blended value creation goals. Small Business Economics, 48(1), 225-257.

Herrera, S. and Kouamé, W. (2017). Productivity in the Non-Oil Sector in Nigeria: Firm-Level Evidence'. Policy Research Working Paper, 8145. Macroeconomics and Fiscal Management Global Practice Group, The World Bank Group, July 2017.

International Fund for Agricultural Development, IFAD (2012). Promoting rural enterprise growth and development: Lessons from four projects in sub-Saharan Africa: Enabling poor rural people to overcome poverty, IFAD, April 2012.

Igwe, P. A., Amarachi, A. N., Ogundana, O. M., Egere, O. M. and Anigbo, J. A. (2018). Factors Affecting the Investment Climate, SMEs Productivity and Entrepreneurship in Nigeria. European Journal of Sustainable Development, 7(1), 1-21.

Igwe, P.A., Icha-Ituma, A. and Madichie, N.O. (2018). An Evaluation of CSR and Social Value Practices Among UK Commercial and Social Enterprises. Entrepreneurial Business and Economics Review, 6(1), 37-52. https://doi.org/10.15678/EBER.2018.060102

Igwe, P.A., Madichie, N.O. and Newbery, R. (2019). Determinants of livelihood choices and artisanal entrepreneurship in Nigeria. International Journal of Entrepreneurial Behavior \& Research, 25(4) 674-697 Publication date: June 2019 https://doi.org/10.1108/IJEBR-02-2018-0102

Igwe, P.A., Newbery, R., Amoncar, N., White, G. R.T. and Madichie, N.O. (2018). Keeping it in the family: exploring Igbo ethnic entrepreneurial behaviour in Nigeria. International Journal of Entrepreneurial Behavior \& Research, https://doi.org/10.1108/IJEBR-12-2017-0492

Igwe, P. A. Newbery, R. and Icha-Ituma, A. (2018). Entrepreneurship challenges and gender issues in the African informal rural economy'. In: Knowledge, learning and innovation, Research insights into Cross-Sector Collaboration. $\quad$ Springer. ISBN 978-3-319-59282-4 https://books.google.co.uk/books?id=z4M0DwAAQBAJ\&pg=PA92\&lpg=PA92\&dq

Igwe, P. A., Onjewu, A.E. and Nwibo, S.U. (2018). Entrepreneurship and SMEs' Productivity Challenges in SubSaharan Africa. African Entrepreneurship. Challenges and Opportunities for Doing Business. Palgrave Macmillan.

Isenberg, D. J. (2010). How to start an entrepreneurial revolution. Harvard Business Review, 88(6), 40-50.

Isenberg, D. J. (2011). The entrepreneurship ecosystem strategy as a new paradigm for economic policy: principles for cultivating entrepreneurship. Presentation at the Institute of International and European Affairs. Dublin, Ireland.

Jaki, A. and Siuta-Tokarska, B. (2019). New Imperative of Corporate Value Creation in Face of the Challenges of Sustainable Development. Entrepreneurial Business and Economics Review, 7(2). https://doi.org/10.15678/EBER.2019.070204

Jones, P., Maas, G., Dobson, S., Newbery, R., Agyapong, D. and Matlay, H. (2018). 'Entrepreneurship in Africa, part 1: entrepreneurial dynamics in Africa. Journal of Small Business and Enterprise Development, 25(3), 346-348.

Keeper, D. G. (2012). Systemic Corruption in Nigeria: A threat to Sustainable Development'. Proceedings of the 1st International Technology, Education, Environment Conference. A Journal of African Society for Scientific Research, 1(1), 172-179.

Kellermanns, F., J. Walter, T. R. Crook, Kemmerer, B. and Narayanan, V. (2016). The Resource-Based View in Entrepreneurship': A Content-Analytical Comparison of Researchers' and Entrepreneurs' Views. Journal of Small Business Management, 54, 26-48.

Khavul, S., G. Bruton, G. and Wood, E. (2009). Informal Family Business in Africa. Entrepreneurship Theory and Practice, 33(6), 1217-1236. 
Khavul, S. (2010). Microfinance: Creating Opportunities for the Poor? Academy of Management Perspectives. pp. 57-97

L'opez-Duarte, C. Vidal-Su'arez, M. M. and Gonz'alez-D'1az, B. (2016). International Business and National Culture: A literature review and research agenda. International Journal of Management Reviens, 18, 397-416.

Mack, E. and Mayer, H. (2015). The evolutionary dynamics of entrepreneurial ecosystems. Urban Studies, 53(10) 2118-2133, DOI: 10.1177/0042098015586547

Maroufkhani, P., Wagner, R., Khairuzzaman, W. and Ismail, W. (2018). Entrepreneurial ecosystems: a systematic review. Journal of Enterprising Communities: People and Places in the Global Economy, 12(4), 545-564.

McKenzie, D. (2015). Identifying and Spurring High-Growth Entrepreneurship Experimental Evidence from a Business Plan Competition. Policy Research Working Paper, 7391. The World Bank. http://documents.worldbank.org/curated/en/210491468178154286/pdf/WPS7391.pdf

McGowan, P., Cooper, S., Durkin, M. and O'Kane, C. (2015). The influence of social and human capital in developing young women as entrepreneurial business leaders. Journal of Small Business Management, 53, pp. 645- 661.

Meghana, A., Demirguc-Kunt, A. and Maksimovic, V. (2011). Firm Innovation in Emerging Markets: The Role of Finance, Governance, and Competition. Journal of Financial and Quantitative Analysis, 46, 1545-80.

Méndez, F. and Sepúlveda, F. (2006). Corruption, Growth and Political Regimes: Cross Country Evidence. European Journal of Political Economy, 22(1): 82-98. doi:10.1016/j.ejpoleco.2005.04.005.

Menzies, T. V., Diochon, M. and Gasse, Y. (2004). Examining Venture-related Myths concerning Women Entrepreneurs. Journal of Developmental Entrepreneurship, 9(2), 89-107.

Méon, P-G. and Sekkat, K. (2005). Does Corruption Grease or Sand the Wheels of Growth? Public Choice, 122 (1-2). Kluwer Academic Publishers: 69-97.

Méon, P-G, and Weill, L. (2010). Is Corruption an Efficient Grease? World Development, 38(3): 244-59. doi:10.1016/j.worlddev.2009.06.004.

Mishra, A., Igwe, P.A. and Lean, J. and Megicks, P. (2014). Supporting micro and small enterprises. In: The Routledge companion to financial services marketing. Routledge Companions in Business, Management and Accounting, 28 (44). Routledge, London, pp. 1-576, https://doi.org/10.4324/9780203517390

Naudè, W. A. and Havenga, J. J. D. (2005). An overview of African entrepreneurship and small business research', Journal of Small Business and Entrepreneurship, 18(1), 101-120.

North, D. C. (1990). Institutions, Institutional Change, and Economic Performance. Cambridge University Press: New York.

Nsengimana, S., Tengeh, R. K. and Iwu, C. J. (2017). The Sustainability of Businesses in Kigali, Rwanda: An Analysis of the Barriers Faced by Women Entrepreneurs. Sustainability, 9(8), 1372-81.

Okunuga, R. O. and Ajeyalemi, D, (2018). Relationship between knowledge and skills in the Nigerian undergraduate chemistry curriculum and graduate employability in chemical-based industries. Industry and Higher Education, 32(3), 183-191, https://doi.org/10.1177/0950422218766913

Organization for Economic Co-operation and Development, (OECD, 2019). Africa. http://www.oecd.org/dev/africa/

Pitan, O. S. (2016). Towards enhancing university graduate employability in Nigeria. Journal of Sociology and Social Anthropology, 7(1): 1-11

Pitan, O. S. (2017). Graduate employees' generic skills and training needs. Higher Education, Skills and WorkBased Learning, 7(3): 290-303

Robb, A. and Coleman, S. and Stangler, D. (2014). Sources of Economic Hope: Women's Entrepreneurship'. SSRN. ELSEVIER. http://dx.doi.org/10.2139/ssrn.2529094

Santos, F. J., Roomi, M.A. and Liñán, F. (2016). About gender differences and the social environment in the development of entrepreneurial intentions. Journal of Small Business Management, 54(1), 49-66.

Terjesen, S. A. (2016). Conditions for High-potential Female Entrepreneurship'. IZA World of Labor.

Williams, C.C. and Kedir, A.M. (2016). The impacts of corruption on firm performance: some lessons from 40 African countries. Journal of Developmental Entrepreneurship, 21(04), 16-22

World Bank (2008). Agriculture for Development. World Development Report. Washington, DC. 
World Bank (2013). 'Gender and Transport.' Washington, DC. The World Bank. http://www.worldbank.org/en/news/press-release/2013/09/24/societies-dismantle-genderdiscrimination-world-bank-group-president-jim-yong-kim Accessed on Dec. 17, 2017

World Bank (2015). Fact Sheet: Doing Business 2016 in Sub-Saharan Africa' October 27, 2015. http://www.worldbank.org/en/region/afr/brief/fact-sheet-doing-business-2016-in-sub-saharanafrica. Accessed March 9, 2017.

World Bank (2019). New country classifications by income level: 2019-2020. World Bank (2019). https://blogs.worldbank.org/opendata/new-country-classifications-income-level-2019-2020

World Economic Forum (2019). How Africa's entrepreneurs are changing the direction of globalization. https://www.weforum.org/agenda/2019/01/african-entrepreneurs-changing-the-direction-ofglobalization/

Zoogah, D. B. (2018). Institutional Risk and Firm Performance in Africa: The Moderating Role of Corruption Control. Africa Journal of Management, 4(4), 401- 425 DOI: $10.1080 / 23322373.2018 .1522172$ 